\title{
Developing Realistic and Child-friendly Learning Model for Teaching Mathematics
}

\author{
Nining Setyaningsih*, Sri Rejeki, Naufal Ishartono \\ Department of Mathematics Education, niversitas Mubammadiyah Surakarta, INDONESLA \\ *Corresponding author: nining.setyaningsih@ums.ac.id
}

\begin{abstract}
This study aims to develop a learning model based on the theory of realistic mathematics education and child-friendly learning for teaching mathematics in junior bigh school. This research is conducted using Plomp's educational design research that consists of four development phases: 1) preliminary investigation, 2) designing, 3) realization, and 4) revision, evaluation. In addition, this study also tests the mathematics instructional model prototype being developed and validated by an expert. Based on the analysis, it can be concluded that: 1) the teacher's learning management in the implementation of realistic and child-friendly learning model can be classified "very good", 2) the prototype model is categorized "very good" in improving students" activities, and 3) the students' responses toward the developed mathematics instructional model are "positive". Moreover, the syntaxes of realistic and child-friendly learning model for teaching mathematics in junior high school have been formulated, namely: 1) explaining learning objectives and motivating students, 2) providing contextual problems students familiar with, or horizontal mathematization, 3) processing abstraction or vertical mathematization, 4) devising strategies, 5) communicating solution in a discussion, and 6) giving inferences of mathematics subject-matter.
\end{abstract}

Keywords: Realistic Mathematics Education, child-friendly, learning model, teaching mathematics

Received: $14^{\text {th }}$ May 2019, Revised: $9^{\text {th }}$ August 2019, Accepted: $13^{\text {th }}$ August 2019

\section{Introduction}

Education is a human conscious effort to develop personalities and abilities according to the values of a society. Moreover, lifelong learning is a characteristic of human. Every human needs education, regardless the time and the space. Formal education carried out in schools cannot be separated from the learning process and interaction between teachers and students. Learning is a relatively permanent change in behavioral potential which occurs as a result of reinforced practice (Johnson, 2008). Therefore, it is presumed that learning may lead to permanent changes in the behavior of both students and teachers as the agents of change. Thus, learning is a sort of assistance provided by teachers for students during the process of acquiring knowledge, mastery or proficiency if a field, character building, and the development of attitudes and beliefs. In other words, learning is a process to help students learn effectively. Meanwhile, teachers become the spearhead with significant role in guiding the learning process of the children of the nation. 
The Indonesian government has recognized and rewarded the Indonesian teachers by positioning them as professional employee as mandated in the Law of Teachers and Lecturers in 2005. Based on this law, a teacher must have four competencies, i.e., pedagogical, professional, personal and social. Pedagogical competence is the ability to manage the learning process including its planning, implementation, and evaluation of the students' learning outcomes (Ada, 2016). Professional competence is the level of acquired knowledge, skills, abilities, informational saturation and other qualities in a specific field of professional activity (Leontyev, Rebrina, Leontyeva, \& Gafiyatullina, 2016). Furthermore, personal competence is the personal ability of self-understanding, self-acceptance, self-direction, and self-realization (Hakim, 2015). While social competence is a comprehensive construct with various facets which refer to cognitive, emotional-motivational, and behavioral aspects (Arnold \& Lindner-müller, 2012). These competencies must be integrated hence the teachers will be able to carry out a high quality learning process.

In mathematics learning, students are required to have the ability to use: 1) mathematics to solve mathematical problems, problems from other subjects, and real world problems, 2) mathematics as a communication tool, and 3) mathematics as a reasoning method that can be used in every situation, such as critical thinking, logical thinking, systematic thinking, as well as the disposition of being subjective, honest, disciplined and cooperative in examining and solving problems (Slamet, 2010). Thus, it implies that the ability of solving problems, reasoning, communication, and cooperation is expected to be achieved through learning mathematics (Lo \& Watanabe, 1997). To realize this expectation, a student-centered learning process is a prerequisite.

The survey conducted by the Directorate General of Higher Education, The Ministry of National Education, Indonesia discloses the phenomenon in which most teachers have low competencies and never received any training program especially pedagogical ones (as cited by Anif, 2012). Another research shows that teachers have a low ability to assess students' learning outcomes and manage the learning process (Widyastono, 2013). Shortly, the results of previous studies indicate that the importance to improve teacher's pedagogical competence. Most teachers still dominate the class instead of involving students in most of learning activities. In other words, they still implement the teacher-centered instead of student-centered instructional approach. Accordingly, it impacts on limited activity and creativity of students in learning.

Mathematical activities, creativity, and communication in learning are the strategy to ensure that students gain a comprehensive understanding of mathematical concepts (Setyaningsih, 2010; Saragih, 2013). Nevertheless, it is difficult to employ such strategy by the teacher's professional competence, the utilization of various learning resources, and the provision of appropriate learning media. Limited learning resources, including literature and media, for learning activities at schools become one of the obstacles in learning process. In addition, the teacher's professional development is also very important. Therefore, it is presumed that a realistic and child-friendly mathematics learning model will be one of the most suitable learning models.

The realistic and child-friendly mathematics learning model is developed by combining realistic learning with enjoyable class situations. Realistic learning is a collaborative learning approach adapted from a teaching-learning strategy called Realistic Mathematics Education (RME). This teaching strategy requires a constructivist approach which greatly emphasizes the capacity of learners and their progress on the basis of their responses. The characteristics of the RME include real world contexts, mathematizing models, learners' own productions and constructions, the interactive character of the teaching process, and intertwinement of various learning strands (Gravemeijer, 1994). Meanwhile, child-friendly refers to the condition in the class which is Safe, Realistic and 
Enjoyable. Safe is the condition where the class protects the learners from bullying from peers, teachers, and other staffs involved in the class. In order to protect the learners from harassment, the classroom activities require the learners to engage them actively in a community and work on real-world problems (realistic). These kinds of activities can promote the learners to enjoy their learning (enjoyable); their joy of learning leads to a lifelong passion for solving problems, understanding, and taking the next step in their thinking.

In fact, there is a discourse on how to develop a learning model based on realistic and child-friendly education. Therefore, the aim of this research is to develop a learning model based on the theory of realistic mathematics education and child-friendly learning for teaching mathematics in junior high school. This research is an effort to support the implementation of the 2013 curriculum and also to improve the creativity of teachers in mathematics learning.

\section{Research Methods}

This research is a development research oriented to devise a product. The product is a child-friendly and realistic mathematical learning model. This study also attempts to develop learning devices in accordance with realistic and child-friendly mathematical learning model. It was conducted at the one of Muhammadiyah Junior High School in Surakarta, Central Java, Indonesia. Subsequently, the model generated from the development process was validated by an expert in mathematics education and mathematic teachers.

The source of the data for the effectiveness of the model is students' outcome. The model used to develop this learning model refers to the educational design research developed by Plomp (1997). It consists of four development phases: 1) preliminary investigation, 2) design, 3) realization, and 4) revision, evaluation, and test. In the first phase, the mathematics instructional models, learning phases, and analysis of mathematics subject-matter in junior high school were investigated. In the second phase, the realistic and child-friendly mathematics learning model was designed. In the third phase, the model was implemented in the classroom and the practicality of the model was observed. Finally, in the last phase, the model would be revised, evaluated, and tested to measure its level of effectiveness.

The sources of data in this study are: 1) experts in the field of model development for the validity of the model, 2) experts in the field of development, researchers and mathematic teachers for the practical assessment of the model, and 3) students as the participant in the implementation of the model for the measurement of model effectiveness.

The analysis technique is used to determine the validity of the model by recapitulating the experts' statements and determining the validity by matching the results with the established criteria. Meanwhile the practicality of the model is measured by recapitulating the experts' statements and determining the practicality by embedding the results with the specified criteria. Furthermore, the effectiveness of the model at the end of the trial is measured by distributing a questionnaire about the implementation of the model and learning activities to students as the participants. The scoring criteria used in this study are presented in Table 1. 
Table 1. Scoring Criteria

\begin{tabular}{|c|c|c|}
\hline Criteria & Scoring Interval & Category \\
\hline Validation of model & $\begin{array}{c}3.5 \leq \text { score }<4 \\
3, .0 \leq \text { score }<3.5 \\
2.0 \leq \text { score }<3.0 \\
1 \leq \text { score }<2\end{array}$ & $\begin{array}{l}\text { Very valid } \\
\text { Valid } \\
\text { Less valid } \\
\text { Invalid }\end{array}$ \\
\hline $\begin{array}{l}\text { Mathematics } \\
\text { teacher's ability in } \\
\text { the managing } \\
\text { learning process }\end{array}$ & $\begin{array}{c}3.5 \leq \text { score }<4 \\
2.5 \leq \text { score }<3.5 \\
\text { score }<2.5\end{array}$ & $\begin{array}{l}\text { Very Good } \\
\text { Good } \\
\text { Poor }\end{array}$ \\
\hline $\begin{array}{l}\text { The response of } \\
\text { students in the } \\
\text { implementation of } \\
\text { the realistic and } \\
\text { child-friendly } \\
\text { learning model }\end{array}$ & $\begin{array}{c}85 \% \leq \text { the students' response } \\
70 \% \leq \text { the students' responses }<85 \% \\
50 \% \leq \text { the students' responses }<70 \% \\
\text { the students' responses }<50 \%\end{array}$ & $\begin{array}{l}\text { Very Positive } \\
\text { Positive } \\
\text { Negative } \\
\text { Very Negative }\end{array}$ \\
\hline $\begin{array}{l}\text { The activity of } \\
\text { students in the } \\
\text { implementation of } \\
\text { the realistic and } \\
\text { child-friendly } \\
\text { learning model }\end{array}$ & $\begin{array}{c}85 \% \leq \text { the students' activity } \\
70 \% \leq \text { the students' activity }<85 \% \\
\text { the students' activity }<70 \%\end{array}$ & $\begin{array}{l}\text { Very Good } \\
\text { Good } \\
\text { Poor }\end{array}$ \\
\hline
\end{tabular}

\section{Results and Discussion}

Preliminary Phase

The preliminary investigation and design phase produce the prototype of the mathematical learning model based on child-friendly and realistic approach with several syntaxes, namely: 1) explaining learning objectives and motivating students, 2) providing contextual problems the students familiar with (horizontal mathematization), 3) conveying abstraction processes (vertical mathematization), 4) formulating strategies, 5) communicating the results of the discussion, and 6) drawing conclusion. The validation of the model showed that the developed learning model, including the requirement, is valid because it met the validity of the constructs and content as presented in Table 2 .

Table 2. The Validation Result of the Developed Learning Model

\begin{tabular}{|c|c|c|c|c|}
\hline \multirow{2}{*}{ No } & \multirow{2}{*}{ Assessment Aspect } & \multicolumn{2}{|c|}{ Score } & \multirow{2}{*}{$\begin{array}{c}\text { Average } \\
\text { Score }\end{array}$} \\
\hline & & Expert 1 & Expert 2 & \\
\hline 1 & Syntax & 3.50 & 3.60 & 3.55 \\
\hline 2 & $\begin{array}{l}\text { The Social system in } \\
\text { class }\end{array}$ & 3.35 & 3.45 & 3.40 \\
\hline 3 & $\begin{array}{l}\text { Implementation of } \\
\text { classroom learning }\end{array}$ & 3.55 & 3.50 & 3.525 \\
\hline \multirow[t]{2}{*}{4} & Evaluation & 3.40 & 3.50 & 3.45 \\
\hline & \multicolumn{3}{|c|}{ Average total score } & 3.48 \\
\hline
\end{tabular}




\section{Realization Phase}

The second phase is the realization of the model, which is the implementation of realistic, child-friendly mathematics learning model in the school. This phase was carried out in two cycles. The description of each cycle is as follows:

\section{The first cycle}

In the first cycle, the topics presented in the learning classroom were distinguished into integers and fractions, compare fractions, and order fractions from smallest to largest as well as from largest to smallest. During the learning process, observations were carried out to find out whether the process was in accordance with the model and tools included in the developed realistic and child-friendly model. Observations were conducted by four experts.

The results of the observations showed that the score for the learning management carried out by mathematics teachers was 2.85. In this model, there are six phases in learning management, namely: 1) the delivery of learning objectives and motivation to students, 2) the delivery of contextual problems students familiar with, 3) the abstraction processes (vertical mathematization), 4) the formulation of strategies, 5) the communication of the results of discussion, and 6) conclusion. So, the score obtained in this phase (2.85) implies that there phases in the learning management have not been fully implemented by the teacher.

In the end of the first cycle, the researchers, teachers, and experts as the observer discussed the implementation of the developed model. The results of the reflection of the first cycle are as follows:

1) There are several phases that have not been implemented properly by the teachers, which are delivering learning objectives and motivating students, providing contextual problems students familiar with, conveying abstraction process, and communicating the results of the discussion. In the first phase, the teachers have neither linked the subject-matter being delivered with the previous subject-matter or apperception nor conveyed the learning objectives. In the second phase, during group discussions, teachers occasionally move around the class but only focus on the active groups. In the third phase, the two teachers do not motivate the students to convey their ideas during group discussions. Finally, in the fifth phase, the teachers only ask one group to read the results of the discussion without facilitating the others to give questions or responses.

2) During group discussions, the teachers do not motivate students to discuss with peers. So, instead of working in groups, students work individually. Moreover, in some groups, only a student who actively completes the tasks.

Based on the observations, reflections, and evaluation of the developed model, it can be identified that the developed model has not been implemented properly. Therefore, several points are formulated to be reviewed, namely: 1) the lesson plan should include time allocation and conformity with the syntaxes of the learning model, 2) the provision of student worksheets, and 3) the additional components of realistic and child-friendly learning model: syntax, social system, and learning implementation.

Based on the review, the lesson plan has contained all phases in the syntaxes but the teachers have not carried out all phases thoroughly. The social system is determined to clarify the teacher's assignments during group discussions as well as students presentations. It stipulates the measures that should be carried out by teachers when the discussion does not work as expected. For example, the teacher should provide questions to encourage students for conveying their ideas or asking questions. Furthermore, in the learning implementation, the role of the teacher should be emphasized, namely as both facilitator and motivator. 
Besides observing the learning management, as the observers, the teachers have to monitor the student activities. These activities involve: 1) expressing opinions or giving explanations, 2) asking questions, 3) making or completing notes, 4) paying attention to the explanation of the teacher or peers. Based on the calculation, about $76 \%$ of students have been participating in those learning activities. In other words, $76 \%$ of students participate in the learning process using realistic and child-friendly model. In addition, the students' response toward the mathematics instructional model is equal to $78.5 \%$. It means that $78 \%$ of students giving responses during the learning process based on the subject matter indicators, student worksheets, difficulties in understanding the subject matter with the developed model, and difficulties in solving problems.

\section{The Second Cycle}

The mathematical subject-matter presented in the second cycle is multiplying and dividing fractions. The results of the observation show that the score of the mathematics teacher's ability in learning management is 3.53. It means that all phases of in the developed model have been carried out during the learning process. In this cycle, the teachers have involved the students to sum up the subject-matters and relate them with real world context. The results of reflection in the second cycle unveil the practicality of the developed learning model to be implemented in the classroom. However, the role of the teachers to motivate the students for expressing their ideas must be improved. Meanwhile, based on the observations on student activities, approximately $92 \%$ of students have been participating in the learning process. In addition, the student response toward the mathematics instructional model is equal to $87 \%$. It implies that $87 \%$ of students have a positive response to the implementation of the developed model. The students' activities in the classroom are portrayed in Figure 1.
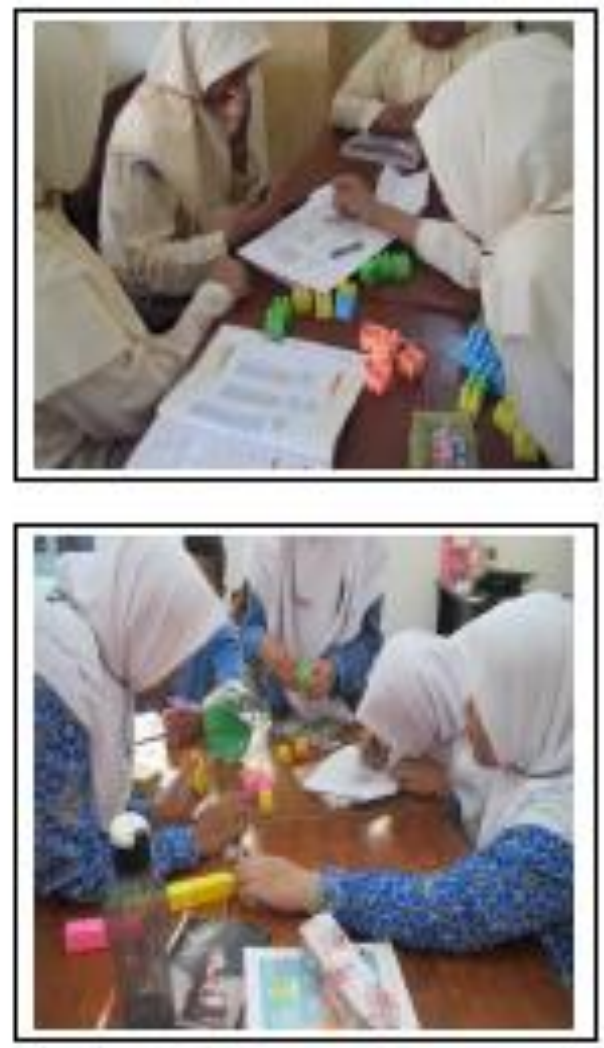
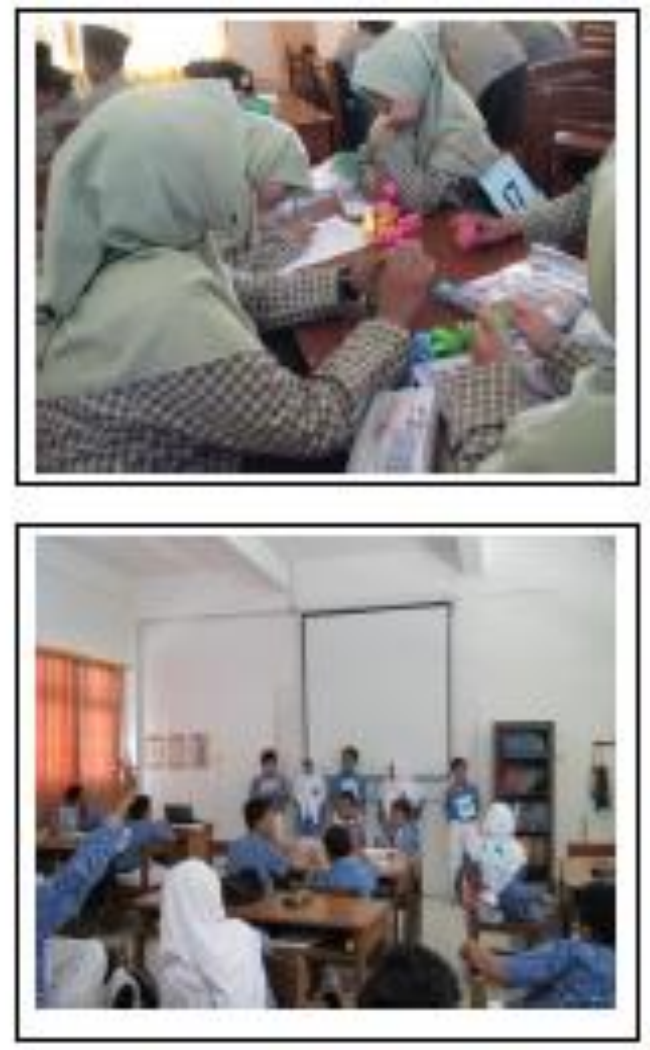

Figure 1. The Activities of Students in the Realistic and Child-friendly Mathematics Learning Model 
The final realistic and child-friendly mathematics learning model

The activities of teachers and students in the realistic and child-friendly mathematics learning model developed in this study are presented in Table 3.

Table 3. Teacher and Student Activities in the Syntax of the Realistic and Childfriendly Learning Model

\begin{tabular}{|c|c|c|}
\hline Phase & Teacher activities & activities \\
\hline $\begin{array}{l}\text { Phase I } \\
\text { Explaining the learning } \\
\text { objectives and } \\
\text { motivating students. }\end{array}$ & $\begin{array}{l}\text { 1. Explain the learning } \\
\text { objectives, } \\
\text { 2. Motivate students by } \\
\text { presenting the usefulness } \\
\text { of the subject-matter to be } \\
\text { taught, both in its relation } \\
\text { to other subjects and daily } \\
\text { life, }\end{array}$ & $\begin{array}{l}\text { 1. Listen carefully to the } \\
\text { learning objectives and } \\
\text { the usefulness of the } \\
\text { subject matter presented } \\
\text { by the teacher, } \\
\text { 2. Respond to the teacher's } \\
\text { questions during the } \\
\text { apperception. }\end{array}$ \\
\hline
\end{tabular}

Phase II

Providing contextual problems which are familiar to students
Phase III

Abstraction process (vertical mathematics)

Phase IV
Formulation of the
strategy

Phase V

Communication of the results

Phase VI

Conclusion

3. Apperception.

Provide contextual problems. In this phase, the teacher is demanded to have creativity and innovation to find contextual problems, so that it can stimulate the student creativity.

The teacher motivates students on how to process the abstraction mathematics.

The teacher motivates students to obtain several possible strategies.

The teacher encourages students to actively participate in giving responses.

Teacher involves the students to make conclusions on the subject-matter being studied.

The observations after the implementation of the developed model find out the ability of the teacher to manage the learning process in the classroom increases from 2.85 in the first cycle to 3.53 in the second cycle. In other words, the category of teacher's ability in managing mathematics learning in the classroom shifts from "good" to "very good". It is the implication for the implementation of the delivery of learning objectives and student motivation, the provision of contextual problems student familiar with, abstraction processes or vertical mathematization, formulation of the strategies, communication of the results of the discussion, and conclusion drawing. Briefly, it can be declared that the teacher ability to manage the learning process improves after the model implementation. 
In addition, the student activities in learning also improve from $76 \%$ to $92 \%$. It shows that the students start to express their opinions and/or give explanations, ask questions, make or complete notes, pay attention to the explanation of the teacher or peers. In other words, the implementation of realistic and child-friendly mathematics learning model motivates students to become more active in the learning process. This finding is in line with previous studies that reveal the intensity of students' activities in expressing opinions or explanations, and asking questions increases after the implementation of realistic-based learning (Veloo \& Ahmad, 2015; Krisnandari, Ardi, Darwis, \& Tahmir, 2015; Setyaningsih, 2016; Slamet, 2010).

The realistic and child-friendly learning model is able to situate the mathematics learning more meaningful. It potentially improves students' creativity and innovation as indicated by their abilities to produce ideas and illustrate them into mathematical models. These activities help students in the process of abstraction or vertical mathematization (abstract and real arguments). The model is then formulated into a solution strategy which is carried out in groups to generate more than one strategy. Accordingly, teachers will be more creative and innovative in preparing the design for teaching mathematics. Problem-based learning model encourages students to actively express their ideas and give questions to peers and teachers (Setyaningsih, 2013). In addition, it has been concluded that by using contextual problems, it would be easier for students, particularly those with a moderate level of mathematics ability, to understand certain topics (Krulick \& Rudnick, 1999; Rejeki, Setyaningsih, \& Toyib, 2017).

In the present study, the realistic and child-friendly learning model is able to help students generate their ideas and then express those ideas in mathematical models. This process is able to help the process of abstraction or vertical mathematization. Thus, the realistic and child-friendly learning model will positively affect students' creativity in solving problems. Moreover, students will be more tolerant to accept others' opinions. In addition, this model will lead students to support each other in a discussion to solve problems together. The impact of this learning model is expected to build student empathy, especially during the learning process.

\section{Conclusion}

This study has developed a realistic and child-friendly learning model for teaching mathematics in junior high school with the syntaxes used to generate the model include: 1) explaining learning objectives and motivating students, 2) providing contextual problems the students familiar with (horizontal mathematization),, 3) conveying abstraction process (vertical mathematization), 4) devising strategies, 5) communicating the results in a discussion, and 6) drawing conclusion 3) conveying abstraction process (vertical mathematization), 4) devising strategies, 5) communicating the results in a discussion, and 6) drawing conclusion. Besides that, the results of the implementation of the realistic and child-friendly learning model also indicates that: 1) the practicality of the developed model is "very good" in which the teachers are able to manage mathematics learning properly, 2) the student activities in teaching and learning activities can be classified "very good", and 3) in overall, the students' response in the implementation of the model is "positive".

\section{Acknowledgement}

We would like to acknowledge UMS for the financial support. Moreover, we also thank to one of Muhammadiyah Junior High Schools in Surakarta as the partners for this program. 


\section{Bibliography}

Ada, J. H. (2016). The contribution of teachers' pedagogical competence toward the effectiveness of teaching of english at mtsn balang-balang. ETERNAL (English, Teaching, Learning and Research Journal), 2(2), 238-251.

Anif, S. (2012). Profesi Guru: Antara Konsep, Implementasi dan Pola Pembinaan. Surakarta Indonesia: FKIP-UMS.

Arnold, K., \& Lindner-müller, C. (2012). Assessment and development of social competence: introduction to the special issue Assessment and development of social competence : introduction to the special issue. Journal for Educational Research Online, 4(1), 7-19.

Gravemeijer, K. (1994). Developing Realistic Mathematics Education. Utrecht: CD-b Press.

Hakim, A. (2015). Contribution of Competence Teacher ( Pedagogical , Personality , Professional Competence and Social ) On the Performance of Learning. The International Journal Of Engineering And Science (IJES), 4(2), 1-12.

Hw, Slamet, \& Setyaningsih, N. (2010). Pengembangan Materi dan Model Matematika Berbasis Media dan Berkonteks Lokal Surakarta Dalam Menunjang KTSP. Surakarta Indonesia.

Johnson, E. B. (2008). Contextual Teaching and Learning: what is it and why it is here to stay. . California : Corwin Press Inc.

Krisnandari, C., Ardi, M., Darwis, M., \& Tahmir, S. (2015). The Application of Realistic Mathematics Education Approach In Teaching Mathematics In Kupang. International Journal of Education and Information Studies, 5, 35-43.

Krulick, S. \& Rudnick, J. A. (1999). Innovative Tasks to Improve Criticalnand Creative Thinking Skills. In Developing Mathematical Reasoning in Grade K-12, pp. 138-145. USA: Prantice Hall.

Leontyev, V. V., Rebrina, F. G., Leontyeva, I. A., \& Gafiyatullina, E. A. (2016). Evaluation of the Development of Professional Competence in Undergraduates: Methodical Aspects. International Journal of Environmental \& Science Education, 11(14), 6592-6602.

Lo, J.-J., \& Watanabe, T. (1997). Developing Ratio and Proportion Schemes: A Story of a Fifth Grader. Journal For Research in Mathematics Education, 28(2), 216-236.

Plomp, T. (1997). Educational and Training System Design. The Netherlands: Univercity of Twente.

Rejeki, S., Setyaningsih, N., \& Toyib, M. (2017). Using LEGO for learning fractions, supporting or distracting? AIP Conference Proceedings , 1848. https://doi.org/10.1063/1.4983954

Saragih, S. (2013). Peningkatan Kemampuan Komunikasi Matematika Siswa SMA di Simpang Ulim Melalui Model pembelajaran Kooperatif Tipe STAD. Jurnal Pendidikan Dan Kebudayaan Kementrian Kependidikan Dan Kebudayaan, 19(, 174-188.

Setyaningsih, N. (2010). Implementasi Model Pembelajaran Problem Posing Untuk Meningkatkan Kemampuan Berfikir Kritis Siswa. Surakarta Indonesia.

Setyaningsih, N. (2013). Implementasi Model Problem Based Learning Dengan Pendekatan Scientifik untuk Meningkatkan Pemabaman Konsep Matematika Siswa. Surakarta Indonesia.

Setyaningsih, N., \& Rejeki, S. (2016). Developing A Mathematics Instructional Model Based On CFICR At Yunior High School. ICRIEMS.

Slamet, H. W., \& Setyaningsih, N. (2010). Pengembangan Materi dan Model Matematika Berbasis Media dan Berkonteks Lokal Surakarta Dalam Menunjang KTSP. Surakarta Indonesia.

Veloo, A., Ali, R., \& Ahmad, H. (2015). Effect of Realistic Education Approach Public Secondary Students In Riau, Indonesia. Australian Journal of Basic and Applied 
Science, 9(28), 131-135.

Widyastono, H. (2013). Minat Terhadap Profesi Guru, Pengetahuan Tenatnag Penilaian

Hasil Belajar dan Kualitan Kurikulum Buatan Guru. Jurnal Penelitian Pendidikan Dan Evaluasi Pendidikan, Vol 19, 222-235. 